\title{
INTRODUCTION THE COASTAL AT RISK INDEX IN THE ROMANIAN BLACK SEA AREA
}

\author{
Article DOI: https://doi.org/10.35219/mtd.2019.3.01 \\ Catalin ANTON, Eugen RUSU \\ University of —Dunarea de Jos\|/Faculty of Engineering, Galati, Romania \\ *Corresponding author: doromir_dragomir@yahoo.com
}

\begin{abstract}
The recent theory of the coastal risk index (C@R) represents a theory, whose approach is based on a series of indicators targeting natural and anthropic processes. These indicators aim to assess the risk of coastal areas exposed to natural hazards (sea level rise, storms, floods etc.). Also, the coastal risk index assesses the degradation of coastal resources and the factors that favor this phenomenon. The C@R index was developed with a special emphasis on coastal and environmental risks and is based on the World Risk Index concept [1].

At the level of the Romanian coastal area, a master plan for protecting the coastal area has been adopted since 2011, a document that has generated several shore protection solutions. During 2014-2017, hard type protection works were carried out in the areas considered the most vulnerable in terms of coastal erosion [2]. The present paper aims to analyze the introduction of a modern risk assessment system by applying the C@R index, at the level of the Romanian coastal area. The purpose of this tool is to help and inform decision makers at all levels about the existing risks, so that they can find solutions to reduce these risks.
\end{abstract}

KEYWORDS: Black Sea, coastal zone, risk index, erosion, coastal risk index

\section{INTRODUCTION}

Coastal dynamics in the context of climate change substantially change the way coastal areas around the globe look and, in some cases, these changes increase the risk of catastrophic damage. Extreme weather phenomena are increasingly influencing the world economy, with GDP rising from $3.6 \%$ in the 1970 s to over $4.3 \%$ in the first decade of the new millennium [3]. Along with the extreme weather phenomena, erosion and floods make an important contribution to the vulnerability of the coastal areas by destroying the infrastructure and affecting the tourism sector, which ultimately brings significant losses to the national economy. In Romania, there can be mentioned the floods from Costinesti, in 2005, that destroyed the protection systems and the beach and jointed Lake Costinesti with the Black Sea, the losses being several tens of millions of euros [4]. Also, the extreme storms of February 2012 destroyed several defense systems and infrastructure, the costs of repairing them being significant. It has become clear that these increasingly frequent coastal processes are threats to the Romanian shoreline [5]. The coastal erosion process was accentuated by recording accelerated erosion rates of approximately $2 \mathrm{~m} /$ year, in several areas, on the Romanian coast [6].There have been total or partial losses of some marine and coastal habitats and many of the coastal protected areas have suffered significant degradation. Globally, coastal habitat losses are extremely important, reaching 50\% for wetlands and $85 \%$ for oyster reefs [7].

It is clear that if no decisions are taken concerning the imposition of control measures, these extreme phenomena will irreversibly endanger the qualities and values of natural and built environment, which could lead to the emergence of social and economic problems, very widespread in the area. The losses could be quantified in transport infrastructure, human properties, cultural and historical heritage, natural landscapes.

There are some aspects that have been taken into consideration when writing this paper. First of all, the fact that the coastal area represents, in general, an area with high risk due to the rapid evolution of some natural and anthropogenic factors. Secondly, the environmental degradation accentuated in this area increases the vulnerability and the risk exposure. Third, if acted upon for the purpose of preserving and restoring the environment, this can lead to reduced exposure to social vulnerability. The last, but not the least, coastal risks can influence climate change, population growth or/and development costs [8]. 
The Coastal Risk Index (C@R) is a tool that helps to understand the risks existing in the coastal areas and shows which environmental degradation problems bring vulnerability. Certain environmental indicators, such as fisheries or habitat indicators, have been linked to vulnerability in order to have a fairer picture of what is happening in the coastal area [9].

\section{METHODOLOGY}

The Coastal Risk Index is a concept based on certain indicators. They assess the impact of areas exposed to natural hazards (floods, cyclones, storms, tsunamis, sea level rise). The coastal risk index also evaluates the environmental degradation in the coastal areas and the resources that contribute substantially to this risk. The C@ $\mathrm{R}$ index was built and developed based on the World Risk Index concept developed by UNU-EHS [10], [11]. To this concept were added attributes of environmental risk and coastal areas. The purpose of this tool was to help local, national, regional and global decisionmakers in terms of the risks they face and what determines them, so that these decision-makers can find the most appropriate solutions. Mitigation and adaptation to climate change have a global impact. The new coastal risk index refers not only to the analysis of a natural phenomenon that is responsible for an imminent disaster, but also to social, economic and ecological elements that can favor or diminish the effects of a calamity. Thus, a special focus is placed on planning processes and proactive measures, capable of mitigating the risks related to climate change in coastal areas.

At the base of the $\mathrm{C} @ \mathrm{R}$ index is a relationship between natural phenomena and the inability of communities to reduce risks. This report actually represents an interaction between an element of natural danger and social vulnerability [12], [13], [14]. The latter is composed of several elements, namely: sensitivity, the ability to cope and the ability to adapt. The concept of the coastal risk index is determined to be not only a result of the probability and magnitude of the natural danger, but is influenced by the way of organization, management and functioning of a community (Fig. 1).

The coastal risk index is made up of 33 indicators, which are based on social, economic, environmental and governance factors. The data for these indicators are usually those that can be obtained free of charge, globally. The indicators are divided into four components, namely, natural hazards, sensitivity, coping ability and adaptability (Fig. 2).

\section{RESULTS}

The results were obtained based on the calculation of the indicators using real data obtained for free from both internal sources, such as the National Statistics Directorate, but also credible external sources, such as World Bank reports or certain reports from the official website of European Union. The indicators were generally applied on a macro scale, the accuracy and availability of local data being not possible. Regarding the indicators, if we talk about those for exposure, they must cover a wide range of natural hazards. Regarding the indicators of sensitivity, coping and adaptability, they must be rational, analytical and well configured statistically, reproducible, adequate, easy to understand and interpret [15].

These indicators selected for World Risk Index have been verified and validated among scientists and practitioners at a symposium in Berlin [16]. Thus, the indicator on the food dependence of the companies in the coastal area has been added, and this indicator is based on the percentage of animal protein from fish.

Also, the revenues from the marine economy were taken into account. These represent a component of lesser or greater importance of the economies of the coastal communities.

Figures 3, 4 and 5 represent the calculation of each proposed indicator for the determination of the coastal risk.

\section{CALCULATION OF THE COASTAL RISK INDEX (C@R)}

The calculation of the index $\mathrm{C} @ \mathrm{R}$ is performed by combining the four elements, namely, exposure, susceptibility, lack of coping capacity and lack of adaptability. Indices of the last three elements are part of a vulnerability index, which is, in turn, a social component of risk, which can transform a natural hazard into a disaster [17]. To calculate the coastal risk index, consider the product between the vulnerability index and the exposure index (Fig. 6). The results are constantly scaled between 0 and 1 [18]. For a better cartographic approach and transformation, it can be classified using the quantum method in an ArcGis Software program. In this case, five classes can be selected, which can be translated into a qualitative classification as follows: "very high - high - medium - low - very low." [19]

\begin{tabular}{|c|c|c|c|}
\hline \multicolumn{4}{|c|}{ COMPONENTS OF THE C@R INDEX } \\
\hline EXPOSURE & SUSCEPTIBILITY & COPING CAPACITY & ADAPTIVE CAPACITY \\
\hline $\begin{array}{l}\text { Exposure to } \\
\text { coastal hazards }\end{array}$ & $\begin{array}{l}\text { Likelihood of } \\
\text { suffering harm }\end{array}$ & $\begin{array}{l}\text { Capacity to reduce } \\
\text { negative consequences }\end{array}$ & $\begin{array}{l}\text { Capacity for long-term } \\
\text { strategies for social change }\end{array}$ \\
\hline $\begin{array}{l}\text { NATURAL HAZARD } \\
\text { SPHERE }\end{array}$ & \multicolumn{3}{|c|}{ VULNERABILITY - SOCIETAL SPHERE } \\
\hline
\end{tabular}

Fig. 1. Scheme of the concept of the C@R Index 


\begin{tabular}{|c|c|c|c|}
\hline EXPOSURE & SUSCEPTIBILITY & COPING CAPACITY & ADAPTIVE CAPACITY \\
\hline $\begin{array}{l}\text { POPULATION } \\
\text { EXPOSED TO }\end{array}$ & PUBLIC INFRASTRUCTURE & $\begin{array}{c}\text { GOVERNMENT AND } \\
\text { AUTHORITIES }\end{array}$ & $\begin{array}{c}\text { EDUCATION AND } \\
\text { RESEARCH } \\
\end{array}$ \\
\hline A. Cyclones & $\begin{array}{l}\text { A. Percentage of population without } \\
\text { access to improved sanitation }\end{array}$ & $\begin{array}{l}\text { A. Corruption } \\
\text { perception index }\end{array}$ & A. Adult literacy rate \\
\hline B. Floods & $\begin{array}{l}\text { B. Percentage of population without } \\
\text { access to improved water source }\end{array}$ & $\begin{array}{l}\text { B. Good governance } \\
\text { [Failed States Index] }\end{array}$ & $\begin{array}{l}\text { B. Combined gross school } \\
\text { enrolment }\end{array}$ \\
\hline $\begin{array}{l}\text { C. Sea Level } \\
\text { Rise }\end{array}$ & NUTRITION & $\begin{array}{l}\text { C. Fish management } \\
\text { effectiveness index }\end{array}$ & GENDER EQUITY \\
\hline $\begin{array}{l}\text { D. Storm } \\
\text { Surges }\end{array}$ & $\begin{array}{l}\text { C. Percentage of population } \\
\text { undernourished }\end{array}$ & MEDICAL SERVICES & $\begin{array}{l}\text { C. Gender parity in } \\
\text { education }\end{array}$ \\
\hline \multirow[t]{11}{*}{ E. Tsunamis } & $\begin{array}{l}\text { D. Percentage of animal protein from } \\
\text { fish }\end{array}$ & $\begin{array}{l}\text { D. Number of } \\
\text { physicians per } 10,000 \\
\text { inhabitants }\end{array}$ & $\begin{array}{l}\text { D. Percentage of female } \\
\text { representatives in the } \\
\text { National Parliament }\end{array}$ \\
\hline & POVERTY AND DEPENDENCIES & $\begin{array}{l}\text { E. Number of hospital } \\
\text { beds per } 10,000 \\
\text { inhabitants }\end{array}$ & $\begin{array}{l}\text { ENVIRONMENTAL } \\
\text { STATUS / ECOSYSTEM } \\
\text { PROTECTION }\end{array}$ \\
\hline & $\begin{array}{l}\text { E. Dependency ratio [share of under } \\
15 \text {-and over } 65 \text {-year-olds in relation } \\
\text { to the working population] }\end{array}$ & $\begin{array}{l}\text { ECONOMIC } \\
\text { COVERAGE }\end{array}$ & $\begin{array}{l}\text { E. Water resources [taken } \\
\text { from EPI2] }\end{array}$ \\
\hline & $\begin{array}{l}\text { F. Extreme poverty population living } \\
\text { with USD } 1.25 \text { per day or less } \\
\text { [purchasing power parity] }\end{array}$ & $\begin{array}{l}\text { F. Insurances [life } \\
\text { insurances excluded] }\end{array}$ & $\begin{array}{l}\text { F. Biodiversity and habitat } \\
\text { protection [EPI] }\end{array}$ \\
\hline & $\begin{array}{l}\text { ECONOMIC CAPACITY AND } \\
\text { INCOME }\end{array}$ & $\begin{array}{l}\text { G. Livelihood diversity } \\
\text { index }\end{array}$ & $\begin{array}{l}\text { G. Forest management } \\
\text { [EPI] }\end{array}$ \\
\hline & G. Gini-Index & & $\begin{array}{l}\text { H. Agricultural } \\
\text { management }[\mathrm{EPI}]\end{array}$ \\
\hline & $\begin{array}{l}\text { H. Marine economic revenue } \\
(\mathrm{OHI} 1) \text { / GDP per country }\end{array}$ & & I. Fish stock status \\
\hline & NATURAL CAPITAL & & INVESTMENT \\
\hline & I. Fish catch & & $\begin{array}{l}\text { J. Public health } \\
\text { expenditure }\end{array}$ \\
\hline & $\begin{array}{l}\text { J. Percentage of population that may } \\
\text { receive risk reduction from reefs and } \\
\text { mangroves [for tropical analyses } \\
\text { only] }\end{array}$ & & K. Life expectancy at birth \\
\hline & & & $\begin{array}{l}\text { L. Private health } \\
\text { expenditure }\end{array}$ \\
\hline
\end{tabular}

Fig. 2 Indicators, components and subcategories of the C@R Index

\begin{tabular}{|c|c|c|}
\hline \multicolumn{3}{|l|}{ SUSCEPTIBILITY } \\
\hline \multicolumn{2}{|l|}{ PUBLIC INFRASTRUCTURE } & \multirow[b]{3}{*}{$22,22 \%$} \\
\hline $\begin{array}{l}\text { A. Percentage of population } \\
\text { without access to improved sanitation }\end{array}$ & $50 \%$ & \\
\hline B. Percentage of population without access to improved water source & $50 \%$ & \\
\hline \multicolumn{2}{|l|}{ NUTRITION } & \multirow{3}{*}{$22,22 \%$} \\
\hline C. Percentage of population undernourished & $50 \%$ & \\
\hline D. Percentage of animal protein from fish & $50 \%$ & \\
\hline \multicolumn{2}{|l|}{ POVERTY AND DEPENDENCIES } & \multirow[b]{3}{*}{$22,22 \%$} \\
\hline $\begin{array}{l}\text { E. Dependency ratio [share of under } 15 \text {-and over } 65 \text {-year-olds in relation } \\
\text { to the working population] }\end{array}$ & $50 \%$ & \\
\hline $\begin{array}{l}\text { F. Extreme poverty population living with USD } 1.25 \text { per day or less } \\
\text { [purchasing power parity] }\end{array}$ & $50 \%$ & \\
\hline \multicolumn{2}{|l|}{ ECONOMIC CAPACITY AND INCOME } & \multirow{5}{*}{$\frac{22,22 \%}{11,11 \%}$} \\
\hline G. Gini-Index & $50 \%$ & \\
\hline H. Marine economic revenue (OHI1) / GDP per country & $50 \%$ & \\
\hline \multicolumn{2}{|l|}{ NATURAL CAPITAL } & \\
\hline I. Fish catch & $100 \%$ & \\
\hline
\end{tabular}

Fig. 3 Calculation of Sensibility Index 
COPING CAPACITY

GOVERNMENT AND AUTHORITIES

A. Corruption perception index

B. Good governance [Failed States Index]

C. Fish management effectiveness index

MEDICAL SERVICES

\begin{tabular}{|l|l|}
\hline D. Number of physicians per 10,000 inhabitants & $33.1 / 3 \%$ \\
\hline
\end{tabular}

E. Number of hospital beds per 10,000 inhabitants $33.1 / 3 \%$

ECONOMIC COVERAGE

F. Insurances [life insurances excluded]

G. Livelihood diversity index

Fig. 4 Calculation of Coping Capacity Index

\begin{tabular}{|c|c|c|}
\hline \multicolumn{3}{|l|}{ ADAPTIVE CAPACITY } \\
\hline \multicolumn{2}{|l|}{ EDUCATION AND RESEARCH } & \multirow{3}{*}{$25 \%$} \\
\hline A. Adult literacy rate & $50 \%$ & \\
\hline B. Combined gross school enrolment & $50 \%$ & \\
\hline \multicolumn{2}{|l|}{ GENDER EQUITY } & \multirow[b]{3}{*}{$25 \%$} \\
\hline C. Gender parity in education & $50 \%$ & \\
\hline D. Percentage of female representatives in National Parliament & $50 \%$ & \\
\hline \multicolumn{2}{|l|}{ ENVIRONMENTAL STATUS / ECOSYSTEM ROTECTION } & \multirow{6}{*}{$25 \%$} \\
\hline E. Water resources [taken from EPI2] & $20 \%$ & \\
\hline F. Biodiversity and habitat protection [EPI] & $20 \%$ & \\
\hline G. Forest management [EPI] & $20 \%$ & \\
\hline H. Agricultural management [EPI] & $20 \%$ & \\
\hline I. Fish stock status & $20 \%$ & \\
\hline \multicolumn{2}{|l|}{ INVESTMENT } & \multirow{4}{*}{$25 \%$} \\
\hline J. Public health expenditure & $33.1 / 3 \%$ & \\
\hline K. Life expectancy at birth & $33.1 / 3 \%$ & \\
\hline L. Private health expenditure & $33.1 / 3 \%$ & \\
\hline
\end{tabular}

Fig. 5. Calculation of Adaptive Capacity Index

\begin{tabular}{|c|c|c|c|}
\hline \multicolumn{4}{|c|}{ C@R INDEX } \\
\hline & \multicolumn{3}{|c|}{ Vulnerability } \\
\hline & $33.1 / 3 \%$ & $33.1 / 3 \%$ & $33.1 / 3 \%$ \\
\hline EXPOSURE & SUSCEPTIBILITY & $\begin{array}{c}\text { LACK OF COPING } \\
\text { CAPACITY }\end{array}$ & $\begin{array}{l}\text { LACK OF ADAPTIVE } \\
\text { CAPACITY }\end{array}$ \\
\hline $\begin{array}{l}\text { Exposure to coastal } \\
\text { natural hazards }\end{array}$ & $\begin{array}{l}\text { Likelihood } \\
\text { suffering harm }\end{array}$ & $\begin{array}{l}\text { Lack of capacity to reduce } \\
\text { negative consequences } \\
\text { during a disaster }\end{array}$ & $\begin{array}{l}\text { Lack of capacity for } \\
\text { long-term strategies for } \\
\text { social change }\end{array}$ \\
\hline
\end{tabular}

Fig. 6. Calculation of C@R Index

\section{DISCUSSIONS}

In terms of exposure, the coastal risk index takes into account both natural hazards that have a sudden onset risk (such as storms, floods, cyclones, tsunamis) but also takes into account natural hazards that have a way of slow start, such as sea level rise [20]. For data concerning phenomena with sudden onset, the PREVIEW Global Platform Data Risk [http: //preview.grid.unep.ch/], can be used, which is a platform where multiple agencies (UNEP, UNDP/BCPR/ GRIP / UNISDR) shared spatial data on global risks due to natural hazards. The existing data on the PREVIEW platform are estimative data of the average annual exposure concerning the natural phenomena mentioned above, as well as the frequency of these events.

If talking about the susceptibility index, this index has a number of 9 indicators divided in 5 subcategories. It should be mentioned here the indicator "fish catch" within the natural subchapter, indicator that was introduced to see the food dependence of the societies in the coastal area to this element.

The coping ability index refers to the ability of a community to respond quickly to the adverse impact of a potential disaster event. Within this index, 7 indicators have been established that aim to 
determine the ability of a coastal community to react quickly or to manage the impact of an unforeseeable event with potential disaster. This index takes into account important resources, such as medical services, economic power, but also structures that could diminish the responsiveness of a coastal community, such as corruption or poor governance [21]. The calculation of coastal risk index will take into account the lack of ability to cope instead of the ability to cope. So, including the calculated value of this index will be subtracted from 1 [22].

Regarding the adaptive capacity of a coastal community, the indicators of this index must take into account the long-term response capabilities regarding natural hazards or environmental changes. This index considers the possibility of transforming or adapting the way of life of a society to reduce the vulnerability in case of changes. This component of the coastal risk index contains four subcategories, namely education and research, gender equity, environmental status and protection, and ecosystem investments [23], [24].

Risk is an extremely complex phenomenon, it has multi-causal components and is not dependent only on natural phenomena or climate change. The risk is based on social causes, which, if properly addressed, can lessen the impact of a disaster. The vulnerability is given by the social side of the risk and is composed of sensitivity, lack of coping capabilities and lack of adaptation capabilities. The results of the coastal risk index describe a potential risk at the level of a coastal area, but it should be kept in mind that this calculation is neither predictive nor probabilistic [25]. No one can predict when and where a dangerous event will take place. On the contrary, this element aims to highlight which of the coastal areas are most exposed to disasters [26].

\section{CONCLUSIONS}

The Coastal Risk Index helps, without any doubt, to understand the risks that may occur in the Romanian coastal area of the Black Sea, as well as the social vulnerability of the community existing here. Also, the $\mathrm{C} @ \mathrm{R}$ index identifies where a vulnerability arises due to environmental degradation [27]. The obtained results can generate a clear picture on the intensity of environmental degradation, but also of means of coping and adapting existing ones. The analysis of the coastal risk index highlights the role that natural resources play in the production of disasters. There is a certain degree of subjectivity and, within this index, first of all, this may be due to insufficient data or the quality of these data, their normalization and any aggregation problems at different scales. As for World Risk Index, its calculation was accepted and approved by practitioners and scientists and published in the literature. When analyzing the reliability of the C@ $\mathrm{R}$ index model, a Cronbachs Alpha $=0.889$ reliability was obtained, which shows a very good correlation between the model results and the input variables. In the case of sensitivity analysis, the indicators had an average greater than zero, which shows that the proposed indicators had a sufficient contribution to the output model. The quality of the input data is very important to generate eloquent results. Some used data, such as data for calculating the quantities of fish or data regarding the total number of tourists on the Romanian coastal area, are quite limited and do not always reflect the reality, and this indicator can influence the result for the coastal risk index. These indicators are not just a particularity of the Romanian shore, such ones can be found in other countries. There is a concern at the level of the various authorities to collect these quantitative indicators, which is an important tool for decision makers [Cutter et al., 2008].

Even if natural events and phenomena, their magnitude and frequency cannot be predictable, or even the impact of climate change, communities can take concrete measures to prevent these events from becoming disasters. When considering economic, social and ecological aspects, communities must assess their vulnerabilities and risks and identify new, innovative approaches. This approach should be based on medium and long term planning and integrate management measures regarding the prevention, protection, preparation and adaptation to climate change.

\section{ACKNOWLEDGMENTS}

This work was supported by the project "Excellence, performance and competitiveness in the Research, Development and Innovation activities at "Dunarea de Jos" University of Galati", acronym "EXPERT", financed by the Romanian Ministry of Research and Innovation in the framework of Programme 1-Development of the national research and development system, Sub-programme 1.2. Institutional Performance. Projects for financing excellence in Research, Development and Innovation, Contract no. 14PFE/17.10.2018.

\section{REFERENCES}

1. Welle T., Beck, M., Mucke, P. (2012) Environmental degradation as a risk factor, in WorldRiskReport 2012, Alliance Development Works, pp. 28-32.

2. Anton C., Gasparotti C., Rusu E., Anton I. A. (2018) Approach to the analysis and evaluation of strategic intervention options in the Romanian coastal zone taking into account economic, social and environmental factors, SGEM 2018, Albena, Bulgaria.

3. Birkmann J., Welle T., Krause D., Wolfertz J., Suarez C. D. \& Setiadi, N. (2011) World Risk Index: concept and results, World Risk Report 2011. Alliance Development Works, pp. 13-42.

4. Anton C., Rusu E., Mateescu R. (2017) An analysis of the coastal risks in Romanian nearshore, Mechanical Testing and Diagnosis, vol. 1, pp. 18-27. 
5. Anton C., Gasparotti C., Raileanu A., Rusu E. (2017) Towards integrated management and planning in the Romanian Black Sea coastal zones, Acta Universitatis Danubius. Oeconomica Journal, Vol. 13, Issue 5, pp. 59-71.

6. Anton I. A, Panaitescu M., Panaitescu F.V. (2017) Optimizing Romanian maritime coastline using mathematical model litpack, 5th Intern. Conf. on Modern Technologies in Industrial Engineering (Modtech), CL Lucian Blaga Univ. Sibiu, Romania, ISSN: 1757-8981

7. UNISDR (United Nations International Strategy For Disaster Reduction) (2009) Global Assessment Report on Disaster Risk Reduction. Risk and Poverty in a Changing Climate -Invest today for a safer tomorrow. United Nations, Geneva, Switzerland.

8. Panaitescu M., Panaitescu F.V., Anton I.A., Anton C. (2016) A Method for Flow Modelling of Vulnerable Areas, Journal of Marine Technology and Environment, vol. 2, pp 43-48.

9. Emerson, J.W., A. Hsu, M.A. Levy, A. de Sherbinin, V. Mara, D.C. Esty, M. Jaiteh (2012) Environmental Performance Index and Pilot Trend Environmental Performance Index. New Haven, Yale Center for Environmental Law and Policy.

10. Birkmann, J., Welle, T., Krause, D., Wolfertz, J., Catalina Suarez, D. \& Setiadi, N. (2011) WorldRiskIndex: Concept and Results. WorldRiskReport 2011. Alliance Development Works, 13-42.

11. Welle, T., Birkmann, J., Krause, D., Suarez, D. C., Setiadi, N., Wolfertz, J. (2013) The WorldRiskIndex: A concept for the assessment of risk and vulnerability at global/ national scales. In Measuring Vulnerability to Natural Hazards: Towards Disaster Resilient Societies, J. Birkmann, 2nd ed. New York: United Nations University, pp. 219-251.

12. $* * *$ UNISDR (International Strategy for Disaster Reduction) (2004) Living with risk: A global review of disaster reduction initiatives (vol. 1). United Nations, New York.

13. Wisner, B., Blaikie, P., Cannon, T. \& Davies, I. (2004). At Risk: Natural Hazards, People's Vulnerability and Disasters. (Routledge) London, New York.

14. Anton C., Anton I. A., Panaitescu F.V., Pana M. (2016) Implementation of a new integrated municipal waste system in Constanta county, Journal of Marine Technology and Environment, vol. 2, pp. 11-15.

15. Meyer, W. (2004) Indikatorenentwicklung. Eine praxisorientierte Einführung (2.Auflage). CEval-
Arbeitspapiere 10, Centrum für Evaluation, Saarbrücken.

16.*** OECD (2008) Handbook on Constructing Composite Indicators. Methodology and User Guide. OECD, Paris.

17. Anton C., Gasparotti C., Rusu E. (2018) Introducing the Blue Economy concept in the Romanian nearshore - SCSS 2018, Galati, Romania 18. Anton C., Gasparotti C., Rusu E. (2018) Identification of the economic pressure in environmental factors in the Romanian coastal zone case study Eforie, SGEM 2018, Albena, Bulgaria 19. Anton C., Gasparotti C., Rusu E. (2018) Analysis of the Mamaia Bay shoreline retreat using hard and soft protection works, SCSS 2018, Galati, Romania.

20. Anton I.A., Panaitescu M., Panaitescu F.V., Ghita S. (2019) Impact of Coastal Systems on Marine Ecosystems, E3S Web Conf., vol. 85, EENVIRO 2018 - Sustainable Solutions for Energy and Environment.

21. Anton I. A., Dinu D. (2017) Wave simulation with different type of coast protection structure. A comparative approach, International Journal of Environmental Science, Vol. 2, pp. 171-176.

22. Anton C., Gasparotti C., Rusu E., (2018) A challenge for the inland navigation - a connection between the Baltic and the Black seas, ICTTE Conference, Belgrad.

23. Adger W. N., Hughes T. P., Folke C., Carpenter S. R., Rockstroem J. (2005) Social-ecological resilience to coastal disasters, Science, 309, pp. 1036-1039.

24. Bankoff G., Frerks G. \& Hilhorst T. (2004) Mapping Vulnerability: Disasters, Development and People, London, Earthscan.

25. Anton I. A., Scupi A., Dinu D. (2018) Nearshore wave processes numerical study for a better prediction of hydrodynamic loads on coastal structures, Modtech Intern. Conf. 2018, IOP Conference Series: Materials Science and Engineering, Vol. 400, 8 - Materials and Technologies in Marine Engineering.

26. Anton I. A., Panaitescu F. V., Panaitescu M. (2017) The influence of hydrotechnical construction on the Romanian morphodynamics coast, 17th Intern. Multidisciplinary Scientific Geoconference SGEM 17(42), pp. 583-590.

27. Anton I. A., Panaitescu M., Panaitescu F. V. (2015) Applications in Matlab Using Finite Element Method, Journal of Marine Technology and Environment, vol. 2, ISSN (online) 1884-6116. 